ECONOMIES OF VIOLENCE 


$$
x
$$




\section{ECONOMIES OF VIOLENCE}

TRANSNATIONAL FEMINISM, POSTSOCIALISM, AND THE POLITICS OF SEX TRAFFICKING 
○ 2015 DUKE UNIVERSITY PRESS. All rights reserved Printed in the United States of America on acid-free paper $\infty$

Designed by Courtney Leigh Baker

Typeset in Minion Pro by Westchester Book Group

Library of Congress Cataloging-in-Publication Data

Suchland, Jennifer, 1974-

Economies of violence : transnational feminism, postsocialism, and the politics of sex trafficking / Jennifer Suchland.

pages $\mathrm{cm}$

Includes bibliographical references and index.

ISBN 978-0-8223-5941-8 (hardcover : alk. paper)

ISBN 978-0-8223-5961-6 (pbk. : alk. paper)

ISBN 978-0-8223-7528-9 (e-book)

1. Human trafficking. 2. Feminism. I. Title.

HQ281.S85 2015

$305.42-\mathrm{dc} 23$

2015008876

Cover design by Natalie F. Smith 
for Shannon 